\title{
Environmental exposure to persistent organic pollutants measured in breast milk of lactating women from an urban area in central Poland
}

\author{
Peter Grešner ${ }^{1}\left(\mathbb{D} \cdot\right.$ Marek Zieliński $^{2} \cdot$ Danuta Ligocka $^{3} \cdot$ Kinga Polańska $^{4} \cdot$ Wojciech Wąsowicz $^{2} \cdot$ \\ Jolanta Gromadzińska ${ }^{2}$
}

Received: 8 July 2020 / Accepted: 7 September 2020 / Published online: 18 September 2020

(C) The Author(s) 2020

\begin{abstract}
Mothers' milk is considered a channel by means of which new-borns are exposed to polychlorinated dibenzo-p-dioxins (PCDDs), polychlorinated dibenzofurans (PCDFs), and dioxin-like polychlorinated biphenyls (dl-PCBs), environmental pollutants entering food chain and accumulating in fat-rich tissues. In this study, the concentrations of selected PCDDs, PCDFs, and dl-PCBs (a total of 29 substances) in milk samples of 110 breast-feeding women from an urban area were analyzed using the high-resolution gas chromatography/high-resolution mass spectrometry method. Environmental exposure to these substances was expressed by means of the World Health Organization Toxicity Equivalent (WHO-TEQ 2005) using the Toxicity Equivalent Factor values from van der Berg et al. (Toxicol. Sci. 93: 223-241, 2006). Concentrations and WHO-TEQ 2005 values were then searched for plausible relationships with selected demographic and diet-related factors. The total WHO-TEQ 2005 toxicity equivalent for all 29 substances was (mean $\pm \mathrm{SD}$ ) $10.57 \pm 4.57 \mathrm{pg} / \mathrm{g}$ fat, while the WHO$\mathrm{TEQ}_{2005}$ levels of PCDDs/PCDFs and dl-PCBs were $7.90 \pm 4.17 \mathrm{pg} / \mathrm{g}$ fat and $2.67 \pm 1.36 \mathrm{pg} / \mathrm{g}$ fat, respectively. The concentration and WHO-TEQ 2005 toxicity equivalent of dl-PCBs correlated significantly with the mothers' age $\left(r_{\mathrm{P}}=\right.$ $0.3814, p<0.00005 ; r_{\mathrm{P}}=0.2817, p<0.005$, respectively). The total WHO-TEQ 2005 toxicity equivalent for all analyzed substances was found to be positively associated with the frequency of consumption of fish and dairy products $(p<0.05$ for both associations). These outcomes must, however, be interpreted cautiously due to limited size of the study. The results of this paper may provide a basis for further studies on the exposure to PCDDs, PCDFs, and dl-PCBs, and mechanisms underlying their action.
\end{abstract}

Keywords PCDDs $\cdot$ PCDFs $\cdot$ dl-PCBs $\cdot$ Breast milk $\cdot$ POPs $\cdot$ Environmental exposure

Peter Grešner and Marek Zieliński contributed equally to this work.

Responsible Editor: Lotfi Aleya

Peter Grešner

peter.gresner@imp.lodz.pl

1 Department of Toxicology and Carcinogenesis, Nofer Institute of Occupational Medicine, 8, Sw. Teresy St., 91-348 Lodz, Poland

2 Department of Biological and Environmental Monitoring, Nofer Institute of Occupational Medicine, Lodz, Poland

3 Bureau of Quality Assurance, Nofer Institute of Occupational Medicine, Lodz, Poland

4 Department of Environmental Epidemiology, Nofer Institute of Occupational Medicine, Lodz, Poland

\section{Introduction}

Polychlorinated dibenzo-p-dioxins (PCDDs) and polychlorinated dibenzofurans (PCDFs) constitute a group of environmental pollutants belonging to the broader group of Persistent Organic Pollutants (POPs). They are produced during many industrial processes, especially in combustion ones and can be found in trace amounts in almost all compartments of the global ecosystem environment. Dioxins are widespread throughout the world and occur in small amounts in the air, soil, water, sediments, and in foods: in dairy products, meat, fish, and crustaceans (Pavan et al. 2006). In 1997, International Agency for Research on Cancer (IARC) classified the 2,3,7,8-TCDD, a substance with the highest Toxicity Equivalent Factor (TEF) TEF = 1 (Van den Berg et al. 2006), as a group 1 carcinogen. Even though the carcinogenic effects 
of dioxins have extensively been studied in animal models, they have not yet been proven in humans. In animal experiments, dioxins have also been shown to exert teratogenic, allergenic, and genotoxic effects (Shertzer et al. 1998). Cases of skin allergies caused by contact with dioxins have been documented in humans as a chlorine acne.

Dioxin-like polychlorinated biphenyls (dl-PCBs), in contrast to PCDDs and PCDFs, were abundantly produced and used in the past. They are among the most stable organic compounds being relatively resistant to degradation under the influence of physical and chemical factors. Their unique properties (non-flammability, low chemical reactivity, high resistance, low dielectric constant, low acute toxicity) have resulted in their wide usage in the industry, predominantly as excellent dielectrics (insulation materials for electric wires, motors, transformers), heat exchangers, but as well as components of hydraulic fluids, flame retardants, printing inks, and additives for glues and plastics. According to official reports from the beginning of the 21 st century, the global production of these compounds reached 1.5 million tons, but this value is assumed to be significantly underestimated (UNEP 2015; Urbaniak 2007; Fielder 2001; Breivik et al. 2007).

A diet is the main source of exposure to dioxins and other POPs. They accumulate in fat-rich tissues, including milk. When accumulated over a long period of time, POPs concentrations in tissues can rise considerably and can be harmful even after a long time from the initial exposure (Kumar et al. 2014).

For a new-born, a mother's milk constitutes the basic source of all necessary nutrients essential for his/her proper development. On the other hand, it also constitutes an important mean by which all the xenobiotics and toxins accumulated in his/her mother's body (including POPs) enter a child's organism. Dioxins are then easily adsorbed in the digestive tract of a new-born - in more than $90 \%$ of the total uptake (Abraham et al. 1994). Among factors affecting infant's exposure to dioxins, a considerable role is played by his/her mother's place of residence - the environmental dioxin pollution is higher in highly urbanized areas then in rural areas (Kamińska et al. 2014; Schuhmacher et al. 2009; Wittsiepe et al. 2007). Other important factors include, obviously, the mother's diet and exposure to tobacco smoke (Ulaszewska et al. 2011).

Exposure of a child to dioxins in a phase of his/her rapid growth and development may result in irreversible changes in normal development of his/her nervous system (WHO 2010). Many recent studies have also shown that pre- and postnatal exposure to dioxins may affect the development and functioning of other organs and systems, including endocrine glands leading potentially to disruption of the child's endocrine system (Stølevik et al. 2013; Legler et al. 2011).

In this study, we aimed to determine the environmental exposure of women and their children to PCDDs, PCDFs, and dl-PCBs by measuring concentration of these substances in a lactating mother's milk. The study also attempted to find statistically significant relationships between concentration of these compounds and selected demographic and diet-related factors (fat-rich diet components, women's age, BMI, the milk fat content).

\section{Materials and methods}

\section{Study group and sampling}

The hereby described study is based on the data from the Polish Mother and Child Cohort study (REPRO_PL), which has been thoroughly described elsewhere (Polańska et al. 2009, 2016). The research material was collected in cooperation with hospitals and obstetric and gynecological clinics within the Lodz district, central Poland, during the REPPRO_PL recruitment period (2007-2011). Women with healthy single pregnancy were recruited for examinations from 8 different regions of Poland. Out of the total of 1266 women with all required data on pregnancy and the new-born recruited within REPRO_PL, only those residing within the urban area of the city of Lodz for at least 5 years with sufficient excess of milk (enough milk for both the child and analysis) were eligible for this study. Ultimately, a total of 110 women aged 16 to 38 years constituted the basis of this study, comprising some $8.7 \%$ of subjects enrolled in the REPRO_PL with available data.

Following 3 to 8 weeks after delivery, the milk was collected from all nursing mothers enrolled in the study in an amount of about $100 \mathrm{ml}$ into glass containers during home visits. After delivery to the laboratory, the milk was stored at $-20{ }^{\circ} \mathrm{C}$ until analysis. Basic characteristics of pregnant women participating in the study, including age, maternal weight before pregnancy, BMI, and milk fat content, were collected from all women meeting the inclusion criteria and are presented in Table 1. Additional information on the frequency of consumption of selected groups of fat-rich food products were also collected from each participant (Table 2).

Table 1 Characteristics of pregnant women participating in the study $(N=110)$

\begin{tabular}{lllll}
\hline & Mean & SD & Min & Max \\
\hline Age (years) & 27.8 & 3.7 & 16.0 & 38.0 \\
Gestational age (weeks) & 39.3 & 1.2 & 37.0 & 42.0 \\
Height (cm) & 166 & 6 & 155 & 183 \\
Weight before pregnancy (kg) & 60.1 & 9.8 & 45.0 & 100.0 \\
BMI & 22.0 & 3.6 & 17.0 & 40.1 \\
Birth weight (g) & 3451 & 472 & 2500 & 4600 \\
Milk fat content (g/l) & 2.0 & 0.7 & 0.6 & 3.9 \\
\hline
\end{tabular}


The study was performed under the guidelines of the Helsinki Declaration for human research and was granted an approval issued by the Local Bioethics Committee of the Nofer Institute of Occupational Medicine (No. 7/2007). Written and informed consent for participation in REPRO PL as well as in this study was obtained from each participant. All data were collected in accordance with the GDPR provision on personal data protection.

\section{PCDDs/PCDFs and dl-PCBs extractions, clean-up, and analysis}

Sample preparation and determination was carried out in accordance with the recommendations of PN-EN 1948-2:2006, PN-EN 1948-3:2006, and U.S. EPA Method 1668, Revision A: Chlorinated Biphenyl Congeners in Water, Soil, Sediment, and Tissue by HRGC/HRMS. US EPA 1999. In accordance with the above-mentioned standards and the Regulation of the Minister of Health for the determination of seven 2,3,7,8substituted PCDDs, ten 2,3,7,8-substituted PCDFs, and twelve dl-PCBs, it is mandatory to use the high-resolution gas chromatography/high-resolution mass spectrometry (HRGC/HRMS). Determination of PCDD/PCDF and dlPCB (as well as fat content) was performed according to the procedure of Kamińska et al. (2014). The developed procedure was accredited by the Polish Centre for Accreditation (PCA, certificate No. AB 215).

Concentrations of PCDDs, PCDFs, and dl-PCBs in analyzed samples were calculated using the QuanLynx/ TargetLynx program. Toxicity of samples was then expressed by means of the World Health Organization Toxicity Equivalent (WHO-TEQ 2005 ), which is the sum of the concentration $\times$ TEF products for considered compounds in the sample. The methodology is thoroughly described in the study by Kamińska et al. (2014).

\section{Statistical analysis}

Concentrations and WHO-TEQ 2005 toxicity equivalents of each compound from the PCDDs, PCDFs, and dl-PCBs groups were both characterized by standard descriptive statistics including mean, standard deviation (SD), median, the upper (UQ) and lower (LQ) quartiles, and minimum (MIN) and maximum (MAX) values. Simple correlations between the parameters describing exposure to analyzed substances on one side and age, BMI, and milk fat content on the other one were characterized by Pearson's correlation coefficient $\left(r_{\mathrm{P}}\right)$. Simple between-group comparisons were investigated using the Kruskal-Wallis $H$ test or the Mann-Whitney $U$ test. Statistical significance was inferred for $p<0.05$.

All statistical analyses were conducted in Statistica 10 package (StatSoft, Tulsa, OK, USA).

\section{Results}

\section{Concentrations of PCDDs, PCDFs, and dl-PCBs in lac- tating mothers' milk}

Seven PCDDs, 10 PCDFs, and 12 dl-PCBs were determined in 110 milk samples collected from the nursing women residing in Lodz, Poland, for a minimum period of 5 years. Out of the hereby analyzed substances, the lowest detection rate was observed for 1,2,3,4,7,8-HxCDD, which we were able to detect in $74.5 \%$ of subjects, while OCDD was the substance with the highest detection rate of $98.2 \%$ of subjects. Detection rates for all other substances were within these boundaries. Respective limits of quantification (LOQ) as well as detection rates for all substances analyzed in this study are provided in Table 3.

The mean concentrations of the sum of 7 PCDDs, the sum of 10 PCDFs, and the sum of 12 dl-PCBs were $58.82 \pm 33.11$ $\mathrm{pg} / \mathrm{g}$ fat, $30.10 \pm 20.26 \mathrm{pg} / \mathrm{g}$ fat, and $6191.92 \pm 3413.63 \mathrm{pg} / \mathrm{g}$ fat, respectively, with corresponding maximum observed values $261.72 \mathrm{pg} / \mathrm{g}$ fat, $110.12 \mathrm{pg} / \mathrm{g}$ fat, and $22052.71 \mathrm{pg} / \mathrm{g}$ fat, respectively. The total WHO-TEQ 2005 toxicity equivalent (for all substances analyzed in the study) of tested samples ranged from 1.59 to $25.17 \mathrm{pg} \mathrm{TEQ} / \mathrm{g}$ fat with mean value of $10.57 \pm 4.57 \mathrm{pg}$ TEQ/g fat. WHO-TEQ 2005 for dioxins and furans ranged from 0.52 to $22.81 \mathrm{pg} \mathrm{TEQ} / \mathrm{g}$ fat, while for dlPCB from 0.02 to $6.00 \mathrm{pg} \mathrm{TEQ} / \mathrm{g}$ fat, with mean values of $7.90 \pm 4.17$ and $2.67 \pm 1.36 \mathrm{pg}$ TEQ/g fat, respectively.
Table 2 Characteristics of pregnant women participating in the study - the frequency of consumption of selected groups of fat-rich diet components

\begin{tabular}{|c|c|c|c|c|c|c|}
\hline \multirow[b]{2}{*}{ Diet component } & \multicolumn{6}{|c|}{ Frequency of consumption } \\
\hline & Never & $\begin{array}{l}\text { Less than once } \\
\text { a week }\end{array}$ & $\begin{array}{l}\text { Once a } \\
\text { week }\end{array}$ & $\begin{array}{l}\text { Twice a } \\
\text { week }\end{array}$ & $\begin{array}{l}\text { More than twice } \\
\text { a week }\end{array}$ & $\begin{array}{l}\text { Every } \\
\text { day }\end{array}$ \\
\hline Fish & 8 & 54 & 36 & 10 & 2 & 0 \\
\hline Meat & 1 & 1 & 2 & 10 & 47 & 49 \\
\hline Milk & 13 & 18 & 8 & 6 & 30 & 35 \\
\hline Dairy products & 6 & 1 & 4 & 10 & 43 & 46 \\
\hline Eggs & 7 & 23 & 32 & 30 & 18 & 0 \\
\hline
\end{tabular}




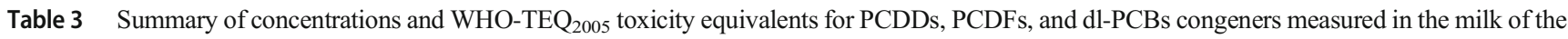
lactating women $(N=110)$ living in Lodz, Poland

\begin{tabular}{|c|c|c|c|c|c|c|c|c|c|c|}
\hline Chemical substance & LOQ & $>\operatorname{LOQ}(\%)$ & Mean & SD & Min & LQ & Median & UQ & Max & IQR \\
\hline 2378-TCDD & 0.1 & 84.5 & 0.90 & 0.73 & 0.1 & 0.27 & 0.81 & 1.36 & 2.69 & 1.09 \\
\hline 12378-PeCDD & 0.5 & 87.3 & 2.38 & 1.92 & 0.5 & 0.90 & 2.19 & 3.49 & 9.09 & 2.58 \\
\hline 123478-HxCDD & 0.5 & 74.5 & 1.64 & 3.22 & 0.5 & 0.02 & 0.78 & 2.12 & 29.72 & 2.10 \\
\hline 123678-HxCDD & 0.5 & 90.9 & 5.45 & 3.04 & 0.5 & 3.45 & 5.54 & 7.32 & 14.81 & 3.87 \\
\hline 123789-HxCDD & 0.5 & 84.5 & 3.11 & 13.18 & 0.5 & 0.45 & 1.50 & 2.79 & 138.54 & 2.34 \\
\hline 1234678-HpCDD & 0.5 & 94.5 & 7.69 & 5.07 & 0.5 & 4.59 & 6.89 & 9.64 & 40.05 & 5.05 \\
\hline OCDD & 1.0 & 98.2 & 37.66 & 25.36 & 1.0 & 23.49 & 33.09 & 48.47 & 218.86 & 24.98 \\
\hline Sum of PCDDs (pg/g fat) & & & 58.82 & 33.11 & 1.84 & 39.2 & 52.87 & 69.67 & 261.72 & 30.47 \\
\hline 2378-TCDF & 0.1 & 94.5 & 0.96 & 1.07 & 0.1 & 0.41 & 0.72 & 1.20 & 6.87 & 0.79 \\
\hline 12378-PeCDF & 0.5 & 77.3 & 1.65 & 1.98 & 0.5 & 0.04 & 1.17 & 2.31 & 9.35 & 2.27 \\
\hline 23478-PeCDF & 0.5 & 96.4 & 7.54 & 3.73 & 0.5 & 5.37 & 7.82 & 9.96 & 17.77 & 4.59 \\
\hline 123478-HxCDF & 0.5 & 94.5 & 3.59 & 2.75 & 0.5 & 1.82 & 3.15 & 4.71 & 14.42 & 2.89 \\
\hline 123678-HxCDF & 0.5 & 90.9 & 2.36 & 1.96 & 0.5 & 1.01 & 1.89 & 2.97 & 9.73 & 1.96 \\
\hline 234678-HxCDF & 0.5 & 88.2 & 3.08 & 3.28 & 0.5 & 0.83 & 1.97 & 4.50 & 19.04 & 3.68 \\
\hline 123789-HxCDF & 0.5 & 80.0 & 1.91 & 3.85 & 0.5 & 0.18 & 0.89 & 2.59 & 36.71 & 2.41 \\
\hline 1234678-HpCDF & 0.5 & 92.7 & 2.66 & 2.45 & 0.5 & 1.08 & 1.97 & 3.82 & 11.45 & 2.74 \\
\hline 1234789-HpCDF & 0.5 & 80.9 & 1.54 & 1.97 & 0.5 & 0.28 & 1.01 & 1.79 & 10.43 & 1.51 \\
\hline OCDF & 1.0 & 83.6 & 4.79 & 6.03 & 1.0 & 0.28 & 3.28 & $6 . .59$ & 29.49 & 6.31 \\
\hline Sum of PCDFs (pg/g fat) & & & 30.10 & 20.26 & 5.10 & 14.52 & 26.56 & 40.68 & 110.12 & 26.16 \\
\hline Sum of PCDFs/PCDDs (pg/g fat) & & & 88.93 & 44.8 & 26.79 & 59.14 & 81.07 & 105.3 & 318.47 & 46.16 \\
\hline WHO-TEQ of PCDDs/ PCDFs (pg TEQ/g fat) & & & 7.90 & 4.17 & 0.52 & 4.82 & 7.42 & 10.41 & 22.81 & 5.59 \\
\hline PCB-81 & 0.02 & 85.5 & 7.12 & 12.18 & 0.02 & 0.82 & 3.24 & 8.28 & 87.10 & 7.46 \\
\hline PCB-77 & 0.02 & 87.3 & 6.73 & 9.57 & 0.02 & 1.94 & 4.33 & 10.32 & 86.45 & 8.38 \\
\hline PCB-123 & 0.02 & 90.9 & 105.22 & 150.97 & 0.02 & 39.39 & 70.25 & 132.68 & 1398.99 & 93.29 \\
\hline PCB-118 & 0.12 & 90.9 & 3326.21 & 1804.87 & 0.12 & 2484.32 & 3142.06 & 4107.66 & 9569.93 & 1623.34 \\
\hline PCB-114 & 0.02 & 90.0 & 139.89 & 82.36 & 0.02 & 89.06 & 140.00 & 186.50 & 398.58 & 97.44 \\
\hline PCB-105 & 0.02 & 83.6 & 617.69 & 465.37 & 0.02 & 394.04 & 557.30 & 806.14 & 2976.09 & 412.1 \\
\hline PCB-126 & 0.02 & 85.5 & 21.04 & 12.31 & 0.02 & 15.16 & 20.64 & 28.27 & 49.54 & 13.11 \\
\hline PCB-167 & 0.02 & 90.9 & 427.42 & 246.74 & 0.02 & 291.31 & 413.72 & 540.43 & 1481.54 & 249.11 \\
\hline PCB-156 & 0.02 & 89.1 & 1223.19 & 947.58 & 0.02 & 777.42 & 1026.05 & 1482.58 & 7164.4 & 705.16 \\
\hline PCB-157 & 0.02 & 90.9 & 273.53 & 160.8 & 0.02 & 178.22 & 248.91 & 361.20 & 781.70 & 182.98 \\
\hline PCB-169 & 0.02 & 95.5 & 13.36 & 12.87 & 0.02 & 7.48 & 10.55 & 15.41 & 110.14 & 7.93 \\
\hline PCB-189 & 0.02 & 92.7 & 144.63 & 104.87 & 0.02 & 83.81 & 128.39 & 170.04 & 701.89 & 86.23 \\
\hline Sum of non-orto dl-PCBs (pg/g fat) & & & 47.92 & 31.27 & 0.06 & 30.92 & 42.21 & 58.47 & 237.07 & 27.55 \\
\hline Sum of mono-orto dl-PCBs (pg/g fat) & & & 6143.99 & 3405.45 & 0.26 & 4198.27 & 5808.22 & 7661.49 & 21971.59 & 3463.21 \\
\hline Sum of dl-PCBs ( $\mathrm{pg} / \mathrm{g}$ fat $)$ & & & 6191.92 & 3413.63 & 18.11 & 4233.4 & 5856.98 & 7723.13 & 22052.71 & 3489.73 \\
\hline \multicolumn{3}{|l|}{ WHO-TEQ of dl-PCBs (pg TEQ/g fat) } & 2.67 & 1.36 & 0.02 & 1.97 & 2.59 & 3.45 & 6.00 & 1.48 \\
\hline \multicolumn{3}{|c|}{ WHO-TEQ of PCDDs/PCDFs/dl-PCBs (pg TEQ/g fat) } & 10.57 & 4.57 & 1.59 & 7.32 & 9.63 & 13.32 & 25.17 & 6.01 \\
\hline
\end{tabular}

Data for the limits of quantification (LOQ) and measured concentrations are provided as pg/g fat, while for the WHO-TEQ 2005 as pg TEQ/g fat. Italic values refer to sums of PCDD, PCDF, and dl-PCB congeners, and WHO-TEQ 2005 values calculated for selected POP groups. $S D$, standard deviation; Min, minimum; $L D$, lower quartile; $U D$, upper quartile; $\operatorname{Max}$, maximum; $I Q R$, interquartile range

In the case of PCDDs and PCDFs, OCDD was found to present the highest mean concentration $(37.66 \pm 25.36 \mathrm{pg} / \mathrm{g}$ fat) representing some $42.3 \%$ of all the compounds in this group, followed by 1,2,3,4,6,7,8-HpCDD $(7.69 \pm 5.07 \mathrm{pg} / \mathrm{g}$ fat) and 2,3,4,7,8-PeCDF (7.54 $\pm 3.73 \mathrm{pg} / \mathrm{g}$ fat), constituting
$8.7 \%$ and $8.5 \%$ of the whole amount of compounds in this group, respectively. Compounds with 4 substituted chlorines-TCDF and TCDD, the most toxic one in this group (TEF $=1$ ) - had the smallest mass share in the group of PCDDs/PCDFs compounds: $1.1 \%$ and $1.0 \%$, respectively. 
Furthermore, PeCDD, the second most toxic compound (TEF $=1$ ), constituted on average some $2.7 \%$ of compounds in this group. Considering dl-PCBs, PCB-118, PCB-156, and PCB105 were the three most abundant ones with mean concentrations of $3326.21 \pm 1804.87 \mathrm{pg} / \mathrm{g}$ fat, $1223.19 \pm 947.58 \mathrm{pg} / \mathrm{g}$ fat, and $617.69 \pm 465.37 \mathrm{pg} / \mathrm{g}$ fat, respectively. Among the most toxic PCBs (non-ortho substituted), PCB-126 (21.04 \pm $12.31 \mathrm{pg} / \mathrm{g}$ fat $)$ and PCB-169 (13.36 $\pm 12.87 \mathrm{pg} / \mathrm{g}$ fat $)$ were the two most abundant. Detailed results are presented in Table 3.

\section{Relationships between concentrations of PCDDs, PCDFs, and dl-PCBs in lactating mothers' milk and selected demographic and diet-related factors}

Summary of Pearson's rank correlation analysis between the parameters describing exposure to PCDDs, PCDFs, and dlPCBs (sum of concentrations, WHO-TEQ 2005 toxicity equivalents) and women's age, BMI, and milk fat content is shown in Table 4. Statistically significant correlations were found only for dl-PCBs, in the case of which the total dl-PCB concentration was positively $\left(r_{\mathrm{P}}=0.3814, p<0.00005\right)$ and negatively $\left(r_{\mathrm{P}}=-0.1993, p<0.05\right)$ correlated with the women's age and the milk fat content, respectively, while the corresponding $\mathrm{WHO}^{-\mathrm{TEQ}_{2005}}$ toxicity equivalent correlated positively with women's age only $\left(r_{\mathrm{P}}=0.2817, p<0.005\right)$. Statistically significant relationships between the mothers' age and parameters related to exposure to dl-PCBs were apparent also following dichotomization of the study group based on median age (28 years): in the subgroup of "younger" mothers (i.e., those with age below the median age), both the summary concentration (below median vs. above median: 4788.5 [3403.8-6564.6] pg/g fat vs. 6907.6 [4772.2$8819.6], p<0.001)$ and the corresponding WHO-TEQ 2005 toxicity equivalent (below median vs. above median: 2.35 [1.69-3.06] pg/g fat vs. 2.94 [2.18-3.77], $p<0.05$ ) of dlPCBs were statistically significantly lower when compared with "older" mothers (i.e., those with age above median value). No other statistically significant correlations or differences were found.
Plausible associations between the parameters of exposure and the frequency of consumption of various diet components were also analyzed. The total WHO-TEQ 2005 toxicity equivalent for all the 29 substances analyzed in the study was considered and as shown in Table 5A, it was found to be significantly associated with the frequency of consumption of fish and dairy products ( $p<0.05$ for both). While the post hoc analysis failed to show any statistically significant differences among individual groups based on the frequency of either fish or dairy products consumption (data not shown), the median levels of total WHO-TEQ 2005 toxicity presented clear progressive increase with increasing fish consumption frequency (Fig. 1). No such clear trend was, however, observed in the case of association between the total WHO-TEQ 2005 total toxicity equivalent and the frequency of consumption of dairy products (see Table 5A).

Due to these interesting outcomes, associations between the fish and dairy products consumption frequency and the WHO-TEQ $_{2005}$ toxicity equivalent of PCDDs/PCDFs and dl-PCBs separately were also analyzed. WHO-TEQ 2005 of PCDDs/PCDFs was found to be significantly associated with the frequency of dairy products consumption $(p<0.05)$, while its association with the frequency of fish consumption remained close to the edge of statistical significance $(p=$ 0.0648). The trend patterns for $\mathrm{WHO}^{-T E Q_{2005}}$ of PCDDs/ PCDFs in terms of its associations with consumption of fish or dairy products consumption resembled those observed in the case of total WHO-TEQ 2005 toxicity equivalents (Table 5B). WHO-TEQ 2005 of dl-PCBs did not show any statistically significant associations with either fish or dairy products consumption frequency (Table 5C).

\section{Discussion}

PCDDs, PCDFs, and dl-PCBs are compounds which, due to their durability and accumulation, are present in various compartments of the environment, from water through sediments or soil to air. From all these compartments, they enter the food
Table 4 Analysis of correlations between parameters of exposure to PCDDs, PCDFs, and dl-PCBs and women's age, BMI, and milk fat content

\begin{tabular}{llll}
\hline & Age & BMI & Milk fat content \\
\hline Sum of PCDDs/PCDFs & 0.1200 & 0.0750 & -0.1602 \\
WHO-TEQ of PCDDs/PCDFs & 0.0491 & 0.0488 & $-0.0447^{\mathrm{c}}$ \\
Sum of dl-PCBs & $0.3814^{\mathrm{a}}$ & 0.0824 & $-0.1993^{\mathrm{c}}$ \\
WHO-TEQ of dl-PCBs & $0.2817^{\mathrm{b}}$ & 0.0666 & $-0.0994^{\mathrm{b}}$ \\
Total WHO-TEQ (PCDDs/PCDFs/dl-PCBs) & 0.1005 & 0.0666 & -0.0423 \\
\hline
\end{tabular}

Presented are the values of the Pearson correlation coefficients for tested correlations between the parameters describing exposure and women's age, BMI, and the milk fat content

${ }^{\mathrm{a}} p<0.00005$

${ }^{\mathrm{b}} p<0.005$

${ }^{\mathrm{c}} p<0.05$ 
Table 5 Associations between total WHO-TEQ 2005 toxicity equivalent and WHO-TEQ 2005 toxicity equivalents of PCDDs/PCDFs and dl-PCBs with selected diet components

\begin{tabular}{|c|c|c|c|c|c|c|c|}
\hline & & \multicolumn{6}{|c|}{ Frequency of consumption } \\
\hline & & Never & Less than once a week & Once a week & Twice a week & More than twice a week & Every day \\
\hline A & & \multicolumn{6}{|c|}{ WHO-TEQ of PCDDs/PCDFs/dl-PCBs (pg TEQ/g fat) } \\
\hline & Fish $^{\text {a }}$ & $8.0[5.8-13.2]$ & $9.1[6.6-12.4]$ & $10.2[8.7-15.5]$ & $10.8[10.1-12.5]$ & $17.5[15.8-19.2]$ & - \\
\hline & Meat & $15.3[15.3-15.3]$ & $9.4[6.3-12.5]$ & $8.8[6.1-12.8]$ & $11.4[7.4-15.8]$ & $9.5[7.3-12.5]$ & $10.2[7.3-14.1]$ \\
\hline & Milk & $8.7[7.2-9.3]$ & $12.5[9.3-15.6]$ & $11.9[10.1-19.8]$ & $9.7[7.9-11.2]$ & $8.8[7.1-12.0]$ & $9.7[5.9-12.9]$ \\
\hline & Dairy products ${ }^{\text {a }}$ & $7.1[5.6-8.7]$ & $16.9[16.9-16.9]$ & $14.9[9.5-19.3]$ & $11.3[7.3-15.6]$ & $9.6[7.1-12.5]$ & $10.0[8.8-12.7]$ \\
\hline & Eggs & $8.3[7.2-15.9]$ & $11.3[7.3-16.0]$ & $9.6[7.9-12.0]$ & $10.2[7.0-15.0]$ & $9.3[6.6-12.7]$ & - \\
\hline \multirow[t]{3}{*}{ B } & & \multicolumn{6}{|c|}{ WHO-TEQ of PCDDs/PCDFs (pg TEQ/g fat) } \\
\hline & Fish $^{\mathrm{b}}$ & $5.6[4.6-10.2]$ & $6.2[4.0-8.7]$ & $8.2[5.4-11.0]$ & $8.5[6.6-9.5]$ & $12.9[10.6-15.1]$ & - \\
\hline & Dairy products ${ }^{\text {a }}$ & $4.5[3.4-5.4]$ & $12.4[12.4-12.4]$ & $12.9[8.2-14.7]$ & $9.8[5.8-10.4]$ & $6.5[4.2-9.2]$ & $7.7[5.6-10.9]$ \\
\hline \multirow[t]{3}{*}{$\mathrm{C}$} & & \multicolumn{6}{|c|}{ WHO-TEQ of dl-PCBs (pg TEQ/g fat) } \\
\hline & Fish & $2.0[0.7-3.2]$ & $2.5[1.8-3.4]$ & $2.5[2.1-3.4]$ & $3.2[1.6-3.8]$ & $4.6[4.1-5.2]$ & - \\
\hline & Dairy products & $2.2[1.7-3.1]$ & $4.5[4.5-4.5]$ & $2.7[1.3-4.7]$ & $2.9[0.2-3.4]$ & $2.5[2.1-3.5]$ & $2.6[2.0-3.2]$ \\
\hline
\end{tabular}

Presented are the respective median values (with interquartile ranges in square brackets) of (A) total (B) PCDDs/PCDFs and (C) dl-PCBs WHO-TEQ 2005 toxicity equivalents in individual groups obtained based on frequency of consumption of selected diet components. Associations between WHO$\mathrm{TEQ}_{2005}$ toxicity equivalents and the frequency of consumption of diet components were tested for significance using the Kruskal-Wallis $H$ test, and post hoc analysis of plausible between-group differences was performed using the standard $z$-test

${ }^{\mathrm{a}} p<0.05$

${ }^{\mathrm{b}} p=0.0648$

directly or indirectly. Food is then considered the main source of intake of dioxins in humans and it is estimated that it constitutes some $90 \%$ of human's overall dioxin intake.

Numerous xenobiotics such as pesticides, plasticizers, or other chemicals intentionally produced and used in the

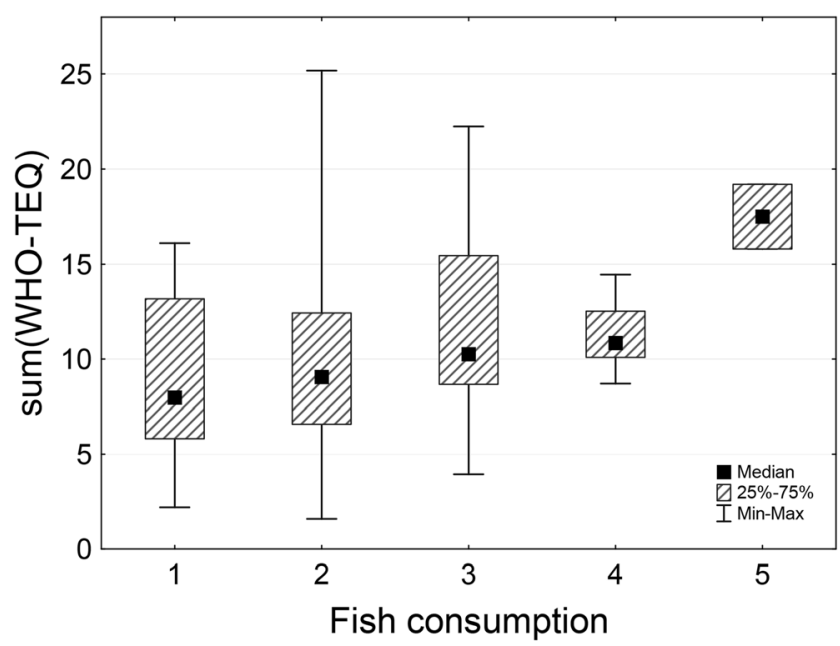

Fig. 1 The relationship between the total WHO-TEQ 2005 toxicity equivalent and the frequency of fish consumption. Shown are the median levels (black squares) together with respective interquartile ranges (shaded rectangles) and min-max ranges (whiskers) of total WHO-TEQ ${ }_{2005}$ toxicity equivalents in individual groups created based on different frequency of fish consumption $(1-$ never, 2 - less than once a week, 3 - once a week, 4 - twice a week, 5 - more than twice a week). Respective values are provided in Table $5 \mathrm{~A}$ industry or agriculture can be controlled-i.e., their production can be reduced or discontinued, or they can be withdrawn from the market. However, environmental pollution can also be caused by unintentionally introduced factors - as a part of improper or ineffective utilization, uncontrolled combustion, especially in home furnaces, but also during fires, especially extensive and uncontrolled forest fires. PCDDs and PCDFs are two examples of such pollutants. Toxicity, bioaccumulation, and their biomagnification in water and land food chains make these compounds a real long-term threat to humans and animals. Such persistent environmental pollutants can be determined by modern analytical techniques at femtogram level and in virtually any environmental matrix. In subsequent stages of food chain, dioxins accumulate in animal fat and adipose tissue; therefore, the amount of human intake depends strictly on a diet used and the preferred food products.

Significant levels of these organic contaminants are accumulated in fat-rich tissues, including breast milk. Breastfeeding milk contains femto- or picogram amounts of PCDDs, PCDFs, and dl-PCBs per gram of fat. For the first few months of a child's life, a mother's milk is its only food. To determine the uptake of the above-mentioned compounds and to assess the effects of such an exposure in infants, proper development of analytical techniques is extremely important. In such studies, the time elapsed between delivery and milk sample collection is crucial, as the milk fat content changes in the subsequent weeks of lactation (Florea 2014). On the other hand, the amount of milk drunk by a growing child rises. 
In the hereby described study, the concentrations of 10 PCDFs, 7 PCDDs, and 12 dl-PCBs (including 4 non-ortho dl-PCBs and 8 mono-ortho dl-PCBs) were determined in a lactating mother's milk samples. The average total WHO$\mathrm{TEQ}_{2005}$ toxicity equivalent (for all the 29 compounds) was $10.57 \pm 4.57 \mathrm{pg}$ WHO-TEQ/g fat, while for PCDDs and PCDFs, it was $7.90 \pm 4.17 \mathrm{pg}$ WHO-TEQ/g fat. The toxicity equivalent for dl-PCBs alone was only $2.67 \pm 1.36 \mathrm{pg}$ WHO$\mathrm{TEQ} / \mathrm{g}$ fat, although dl-PCB concentrations were significantly higher than those determined for dioxins and furans. This is due to the lower toxicity of dl-PCBs compared with the one of PCDDs or PCDFs, and especially to the most dangerous of them-2,3,7,8-TCDD and 1,2,3,7,8-PeCDD, for which the value of TEF is equal to 1 . Very similar results were obtained in a work by Lu et al. (2015). They have determined the levels of dioxins, furans, and biphenyls in the milk of lactating women living in urban areas in China. The average WHO-TEQ 2005 in their study was $8.3 \mathrm{pg} \mathrm{WHO}-\mathrm{TEQ} / \mathrm{g}$ fat, which is slightly lower than the value obtained by us, and the $\mathrm{WHO}^{-\mathrm{TEQ}_{2005}}$ toxicity equivalents for PCDDs/PCDFs and dl-PCBs individually were 2.9 and $5.4 \mathrm{pg}$ WHO-TEQ/g fat, respectively. The authors themselves note that the toxicity equivalents they obtained in their study are lower compared with those reported from other countries, but point, at the same time, to higher concentrations of POPs (especially dl-PCBs) in milk taken from women living in urban areas. In our work, this relationship was also noticed (data not shown). The mean concentrations of the most toxic among dioxins (TCDD and PeCDD) were $0.90 \pm 0.73$ and $2.38 \pm 1.92 \mathrm{pg} / \mathrm{g}$ fat, respectively, while the mean concentration of the most commonly occurring dioxin-OCDD — was $37.66 \pm 25.36 \mathrm{pg} / \mathrm{g}$ fat. In the case of dlPCBs, PCB-118 congener turned out to be the most common compound. This congener is a compound most frequently found in both biological (milk, blood) and environmental (sediments, ashes, or water) matrices (Zieliński et al. 2014, Urbaniak et al. 2008, 2014). Its mean concentration was $3326 \pm 1804.87 \mathrm{pg} / \mathrm{g}$ fat, while the maximum determined value was as much as $9570 \mathrm{pg} / \mathrm{g}$ fat. Similarly, in the case of the OCDD congener, it has also been the most common one among dioxins and significantly affects the total amount of all PCDDs in the sample (Zieliński et al. 2014; Urbaniak et al. 2012, 2014). Nevertheless, its contribution to total toxicity of the entire sample is insignificant. The results obtained by $\mathrm{Lu}$ et al. (2015) were similar. OCDD was also predominant among the dioxins, while PCB-118, with its mean concentration of approx. $1896 \mathrm{pg} / \mathrm{g}$ fat, definitely exceeded concentrations of other dl-PCBs.

In a study by Manh et al. (2015), reporting the concentrations of dioxins in milk of nursing mothers living in dioxincontaminated cities in Vietnam, the determined WHO$\mathrm{TEQ}_{2005}$ toxicity equivalent was found to be $9.3 \mathrm{pg}$ WHO$\mathrm{TEQ} / \mathrm{g}$ fat. It is also interesting that $2,3,7,8-\mathrm{TCDD}$, the most dangerous dioxin, constituted over $23 \%$ of all measured congeners, while other compounds had a significantly smaller mass share. It is completely different from our findings in the case of which the pollution came only from urban development and traffic, and the mass share of TCDD constituted only some $1 \%$. In the cities distant from places contaminated with dioxins, the share of tetrachlorodibenzo- $p$-dioxin is smaller, while higher concentrations of other compounds, also from the PCDFs group, show up. However, OCDD still remains a congener with the highest concentrations-irrespective of whether measured in cities in dioxin-polluted areas or in the cities away far from such. In Europe, high concentrations of dioxins and biphenyls in milk of lactating women have been found in France (Focant et al. 2013). Although concentrations of the most dangerous dioxins - TCDD and PeCDD - were only $0.80 \mathrm{pg} / \mathrm{g}$ fat and $1.62 \mathrm{pg} / \mathrm{g}$ fat, respectively, which is slightly lower compared with our study, the total WHO$\mathrm{TEQ}_{2005}$ equivalent was as high as $17.81 \mathrm{pg}$ WHO-TEQ/g fat (compared with $10.57 \mathrm{pg} / \mathrm{g}$ fat in our present study). Respective value for dl-PCBs was $7.69 \mathrm{pg} \mathrm{WHO-TEQ/g}$ fat, compared with $2.67 \mathrm{pg} / \mathrm{g}$ fat in our study. These values were higher than those presented by us mainly due to high concentrations of polychlorinated biphenyls (the highest value for PCB-118) but above all, mainly by high HxCDD values, which were at considerably lower level in our study. Besides that, our data are comparable with those from other places throughout Europe. Comparing the range of PCDDs/PCDFs and PCBs levels in milk determined in the WHO studies between 2006 and 2009, the levels found among the Polish mothers' milk and reported here in our study surely fit into rather medium and lower part of such range. Out of the cited studies, the highest concentrations were definitely determined in milk samples from Moldova, the Czech Republic, and Luxembourg, where dioxins were found to be at the levels exceeding $20 \mathrm{pg}$ WHO-TEQ/g fat (ranging from 16 to $47 \mathrm{pg}$ WHO-TEQ/g fat). In Belgium and Slovakia, the values were above $15 \mathrm{pg} \mathrm{WHO}-\mathrm{TEQ} / \mathrm{g}$ fat (ranging from 16 to $52 \mathrm{pg}$ WHO-TEQ/g fat). The lowest levels of $\mathrm{WHO}^{-\mathrm{TEQ}_{2005}}$ were obtained in Fiji and Ghana-below 6 pg WHO-TEQ/g fat (Adu-Kumi et al. 2010). Slightly lower concentrations than those presented in our study were found in samples collected from lactating women in Cyprus (an average of $7.0 \mathrm{pg}$ WHO$\mathrm{TEQ} / \mathrm{g}$ fat) and South Korea (an average of $6.5 \mathrm{pg}$ WHOTEQ/g fat; Adu-Kumi et al. 2010). A large pool of samples $(n=300)$ was analyzed by Canadian researchers (Ryan and Rawn 2014), who reported levels comparable with ours (8.3 pg WHO-TEQ/g fat). In addition, TCDD, PeCDD, and OCDD concentrations were also close to those observed by us (mainly in the case of dl-PCBs). The authors of this Canadian study have also shown that in some regions of Canada, the exposure to dioxins through the milk of lactating women decreased over the years 1992 to 2005.

$\mathrm{Lu}$ et al. (2015) have recently reported an association between a diet of women participating in their study and the 
concentration of POPs. According to their study, higher fish consumption translates into higher levels of dioxins in milk, resulting in a greater exposure of new-borns to PCDDs/ PCDDFs and dl-PCBs. This seems to be confirmed by outcomes of our study, in which we observed a positive association between the frequency of fish consumption and the level of total WHO-TEQ 2005 toxicity equivalent, which most probably could be attributable mainly to dioxins, as WHO$\mathrm{TEQ}_{2005}$ toxicity equivalent of PCDDs/PCDFs, contrary to the WHO-TEQ 2005 equivalent of dl-PCBs, retained such positive association with the frequency of fish consumption, once analyzed separately.

On the other hand, our outcomes seem to suggest statistically significant associations also between the frequency of consumption of dairy products and the total WHO-TEQ $_{2005}$ equivalent as well as the $\mathrm{WHO}^{-T_{E} Q_{2005}}$ equivalent for PCDDs/PCDFs only. Nevertheless, the interpretation of these findings is peculiar as in these cases no such clear positive trend of increasing values of toxicity equivalents with increased consumption of dairy products was observed (see Table 5). Outcomes concerning such associations with the frequency of consumption of dairy products must be thus treated with caution, especially in the light of very few subjects in certain groups involved in these analyses.

\section{Conclusions}

In this study, the concentrations of 29 compounds from the POPs group (PCDDs, PCDFs, and dl-PCBs) in the milk of lactating women living in Lodz, the third largest city in Poland, are presented. The obtained results fit well within the range of results reported by other authors throughout Europe as well as in the world. The profile of individual congeners indicates that POPs pollution occurring in the area where the research was carried out was caused mainly by traffic (highly urbanized area) or uncontrolled burning, especially garbage, unfortunately in home furnaces. This is a problem that requires constant monitoring due to the fact that the concentration of dioxins, which are very persistent, will not decrease. Their accumulation in the environment and human body will lead to progressive rise of these concentrations in years to come; thus, the exposure of newborns drinking their mothers' milk in the first weeks of their life could be considerably higher.

The study also reports certain interesting associations between the concentration of analyzed POPs and age as well as with the frequency of consumption of some diet components, especially fish. These associations need to be, however, treated with caution as they definitely deserve further verification in much larger studies.
Authors' contributions Peter Grešner: conceptualization, formal analysis, data curation, writing - review and editing, visualization; Marek Zieliński: conceptualization, methodology, investigation, writingoriginal draft; Danuta Ligocka: methodology, validation; Kinga Polańska: resources, writing - review and editing; Wojciech Wąsowicz: project administration, funding acquisition; Jolanta Gromadzińska: supervision, writing - review and editing.

Funding The study was supported by the Nofer Institute of Occupational Medicine statutory fund No. IMP 9.9/2019.

Data availability All datasets used and/or generated during the current study are available from the corresponding author upon reasonable request.

\section{Compliance with ethical standards}

Competing interests The authors declare that they have no competing interests.

Ethical approval The study was performed under the guidelines of the Helsinki Declaration for human research and was approved by the Bioethics Committee of the Nofer Institute of Occupational Medicine (resolution no. 7/2007).

Consent to participate Written and informed consent for participation in this study was obtained from each participant.

Consent to publish Not applicable.

Open Access This article is licensed under a Creative Commons Attribution 4.0 International License, which permits use, sharing, adaptation, distribution and reproduction in any medium or format, as long as you give appropriate credit to the original author(s) and the source, provide a link to the Creative Commons licence, and indicate if changes were made. The images or other third party material in this article are included in the article's Creative Commons licence, unless indicated otherwise in a credit line to the material. If material is not included in the article's Creative Commons licence and your intended use is not permitted by statutory regulation or exceeds the permitted use, you will need to obtain permission directly from the copyright holder. To view a copy of this licence, visit http://creativecommons.org/licenses/by/4.0/.

\section{References}

Abraham K, Hille A, Ende M, Helge H (1994) Intake, faecal excretion of PCDDs, PCDFs, HCB and PCBs $(138,153,180)$ in breast-fed and formula-fed infants. Chemosphere 29:2279-2286

Adu-Kumi S, Malisch R, Kotz A, Kypke K, Asante KA, Takahashi S, Tanabe S, Takasuga T, Clarke E, Weber R (2010) Levels of persistent organic pollutants (POPs) in human breast milk samples from Ghana. Organohalogen Compd 72:1046-1049

Breivik K, Sweetman A, Pacyna JM, Jones KC (2007) Towards a global historical emission inventory for selected PCB congeners - a mass balance approach: 3. An update. Sci Total Environ 377:296-307

Fielder H (2001) Global and local disposition of PCB. In: Robertson LW, Hanssen LG (eds) PCBs-recent advances in the environmental toxicology and health effects. University Press of Kentucky, Kentucky, pp 11-15 
Florea M (2014) Laktacja i karmienie piersią. Przegląd piśmiennictwa. Perinatol Neonatol Ginekol 7(3):165-170

Focant JF, Frery N, Bidondo M-L, Eppe G, Scholl G, Saoudi A, Oleko A, Vandentorren S (2013) Levels of polychlorinated dibenzo-p-dioxins, polychlorinated dibenzofurans and polychlorinated biphenyls in human milk from different regions of France. Sci Total Environ 452-453:155-162

Kamińska J, Ligocka D, Zieliński M, Czerska M, Jakubowski M (2014) The use of PowerPrep and HRGC/HRMS for biological monitoring of exposure to PCDD, PCDF and dl-PCB in Poland. Int J Hyg Environ Health 217:11-16

Kumar J, Lind PM, Salihovic S, van Bavel B, Lind L, Ingelsson E (2014) Influence of persistent organic pollutants on oxidative stress in population-based samples. Chemosphere 114:303-309

Legler J, Hamers T, van Eck van der Sluijs-van de Bor M, Schoeters G, van der Ven L, Eggesbo M, Koppe J, Feinberg M, Trnovec T (2011) The OBELIX project: early life exposure to endocrine disruptors and obesity. Am J Clin Nutr 94(suppl):1933S-1938S

Lu D, Lin Y, Feng C, Wang D, She J, Shen H, Wang G, Zhou Z (2015) Levels of polychlorinated dibenzo-p-dioxins/furans (PCDD/Fs) and dioxin-like polychlorinated biphenyls (DL-PCBs) in breast milk in Shanghai, China: A temporal upward trend. Chemosphere 137:14 24

Manh HD, Kido T, Tai PT, Okamoto R, Honma S, Liang SX, Anh LT, Maruzeni S, Nghi TN, Nishijo M, Nakagawa H, Nhu DD, Tung DV, Hung NN, Son LK (2015) Levels of polychlorinated dibenzofurans in breast milk samples from three dioxin-contaminated hotspots of Vietnam. Sci Total Environ 511:416-422

Pavan M, Todeschini R, Orlandi M (2006) Data mining by total ranking methods, a case study on optimisation of the "pulp and bleaching" process in the paper industry. Ann Chim 96:13-27

Polańska K, Hanke W, Gromadzinska J, Ligocka D, Gulczynska E, Sobala W, Wasowicz W (2009) Polish mother and child cohort study - defining the problem, the aim of the study and methodological assumptions. Int J Occup Med Environ Health 22:383-391

Polańska K, Hanke W, Król A, Potocka A, Waszkowska M, Jacukowicz A (2016) Polish mother and child cohort study (REPRO_PL) methodology of the follow-up of the children at the age of 7. Int J Occup Med Environ Health 29(6):883-893

Ryan JJ, Rawn DFK (2014) Polychlorinated dioxins, furans (PCDD/Fs) and polychlorinated biphenyls (PCBs) and their trends in Canadian human milk from 1992 to 2005. Chemosphere 102:76-86

Schuhmacher M, Kiviranta H, Rouk Ojarvi P, Nadal M, Domingo JL (2009) Concentrations of PCDD/Fs, PCBs and PBDEs in breast milk pf women from Catalonia, Spain: a follow-up study. Environ Int 35:607-613

Shertzer HG, Nebert DW, Puga A, Ary M, Sonntag D, Dixon K, Robinson LJ, Cianciolo E, Dalton TP (1998) Dioxin causes a sustained oxidative stress response in the mouse. Biochem Biophys Res Commun 253:44-48
Stølevik SB, Nygaard UC, Namork E, Haugen M, Meltzer HM, Alexander J, Knutsen HK, Aaberge I, Vainio K, van Loveren H, Løvik M, Granum B (2013) Prenatal exposure to polychlorinated biphenyls and dioxins from the maternal diet may be associated with immunosuppressive effects that persist into early childhood. Food Chem Toxicol 51:165-172

Ulaszewska MM, Zuccato E, Davoli E (2011) PCDD/Fs and dioxin-like PCBs in human milk and estimation of infants' daily intake: a review. Chemosphere 83:774-782

UNEP (2015) Conference of the Parties to the Stockholm Convention. Preliminary assessment of efforts made toward the elimination of polychlorinated biphenyls Report No. UNEP/POPS/COP.7/INF/9, 1-40 (UNEP, Geneva, Switzerland).

Urbaniak M (2007) Polychlorinated biphenyls: Sources, distribution and transformation in the environment - a literature review. Acta Toxicol 15:83-93

Urbaniak M, Kiedrzyńska E, Zieliński M, Tołoczko W, Zalewski M (2014) Spatial distribution and reduction of PCDD/PCDF toxic equivalents along three shallow lowland reservoirs. Environ Sci Pollut Res 21:4441-4452

Urbaniak M, Skowron A, Zieliński M, Zalewski M (2012) Hydrological and environmental conditions as key drivers for spatial and seasonal changes in PCDD/PCDF concentrations, transport and deposition along urban cascade reservoirs. Chemosphere 88:1358-1367

Urbaniak M, Zieliński M, Wesołowski W, Zalewski M (2008) PCBs and heavy metals contamination in bottom sediments from three reservoirs of different catchment characteristics. Polish J of Environ Stud 17:941-949

Van den Berg M, Birnbaum LS, Denison M, de Vito M, Farland W, Feeley M, Fiedler H, Hakansson H, Hanberg A, Haws L, Rose M, Safe S, Schrenk D, Tohoyama C, Tritscher A, Tuomisto J, Tysklind M, Walker N, Peterson RE (2006) The 2005 World Organization reevaluation of human and mammalian toxic equivalency factors for dioxins and dioxin-like compounds. Toxicol Sci 93:223-241

WHO (2010) Dioxins and their effects on human health. Fact sheet No 225. http://www.who.int/mediacentre/factsheets/fs225/en/index. html. Accessed Apr 2019

Wittsiepe J, Furst P, Schrey P, Lemm F, Kraft M, Eberwein G, Winneke G, Wilhelm M (2007) PCDD/F and dioxin-like PCB in human blood and milk from German mothers. Chemosphere 67:286-294

Zieliński M, Kamińska J, Czerska M, Ligocka D, Urbaniak M (2014) Levels and sources of PCDDs, PCDFs and dl-PCBs in the water ecosystems of central Poland - a mini review. Int J Occup Med Environ Health 27:902-918

Publisher's note Springer Nature remains neutral with regard to jurisdictional claims in published maps and institutional affiliations. 